\title{
New light on the warrior stelae from Tartessos (Spain)
}

\author{
Sebastián Celestino Pérez ${ }^{1} \&$ Carolina López-Ruiz ${ }^{2}$
}

The famous stelae from the Tartessos region of southern Iberia are compared with new discoveries from the Levant. Similarities of theme and iconography endorse the Phoenician connection, but show it to be more a cultural dialogue between east and west than an imposition by colonists.

Keywords: Stelae, Tartessos, Beth-Saida, bulls, orientalising, colonisation, syncretism

\section{Introduction}

We owe the name Tartessos to Graeco-Roman tradition (cf. Herodotus $4.152 \mathrm{ff}$. and 1.163, 165, Ephoros GGM 1. P. 201, Avienus Ora Maritima, etc.), and much scholarship has been dedicated to sorting out myth from history and re-defining what was intended by the name through the critical reading of the ancient sources and the increasing archaeological evidence. Today we understand Tartessos as an indigenous culture that developed in the south-west of the Iberian Peninsula (modern Spain and Portugal), expanding from an original nucleus in the lower Gaudalquivir (today's south-west Andalucía) (see Figure 1). The flourishing of this culture has long been associated with the impact of Phoenician colonisation during the eighth to sixth centuries BC, with clear signs of crisis and decline in the fifth century BC. The term 'orientalising', applied to this short period, refers to the cultural impact produced by the contact between the Levantine peoples and the European societies of the Mediterranean realm.

Some of the most tangible transformations in Tartessic culture due to this process were the beginning of proto-urbanism and the introduction of the wheel in pottery manufacture. In fact, the general strategy of investigation nowadays is to consider Tartessos as a trading community composed of a number of proto-urban settlements, with an economic focus on maritime trade built upon agricultural and mineral exploitation of the hinterland.

The phenomenon of the so-called warrior stelae of the south-west of the Iberian Peninsula, around the ninth to eighth centuries BC, has become a key element in understanding the social complexity of the indigenous populations associated with the site of Tartessos. New opportunities for studying the nature of the contact with the eastern Mediterranean have arisen from the discovery of a monumental stela in 1997 dating to the eighth century BC at the excavations of Beth-Saida, on the north-east coast of the Sea of Galilee (Israel) (Barnett

$1 \quad$ Instituto de Arqueología, de Mérida. Consejo Superior de Investigaciones Cientificas, Mérida 06800, Spain (Email: scelestino@iam.csic.es)

2 Department of Greek and Latin, The Ohio State University, Columbus, OH 43210, USA (Email: lopez-ruiz.1@ osu.edu)

Received: 22 November 2004; Accepted: 9 May 2005; Revised: 18 May 2005

ANTIQUiTy 80 (2006): 89-101 


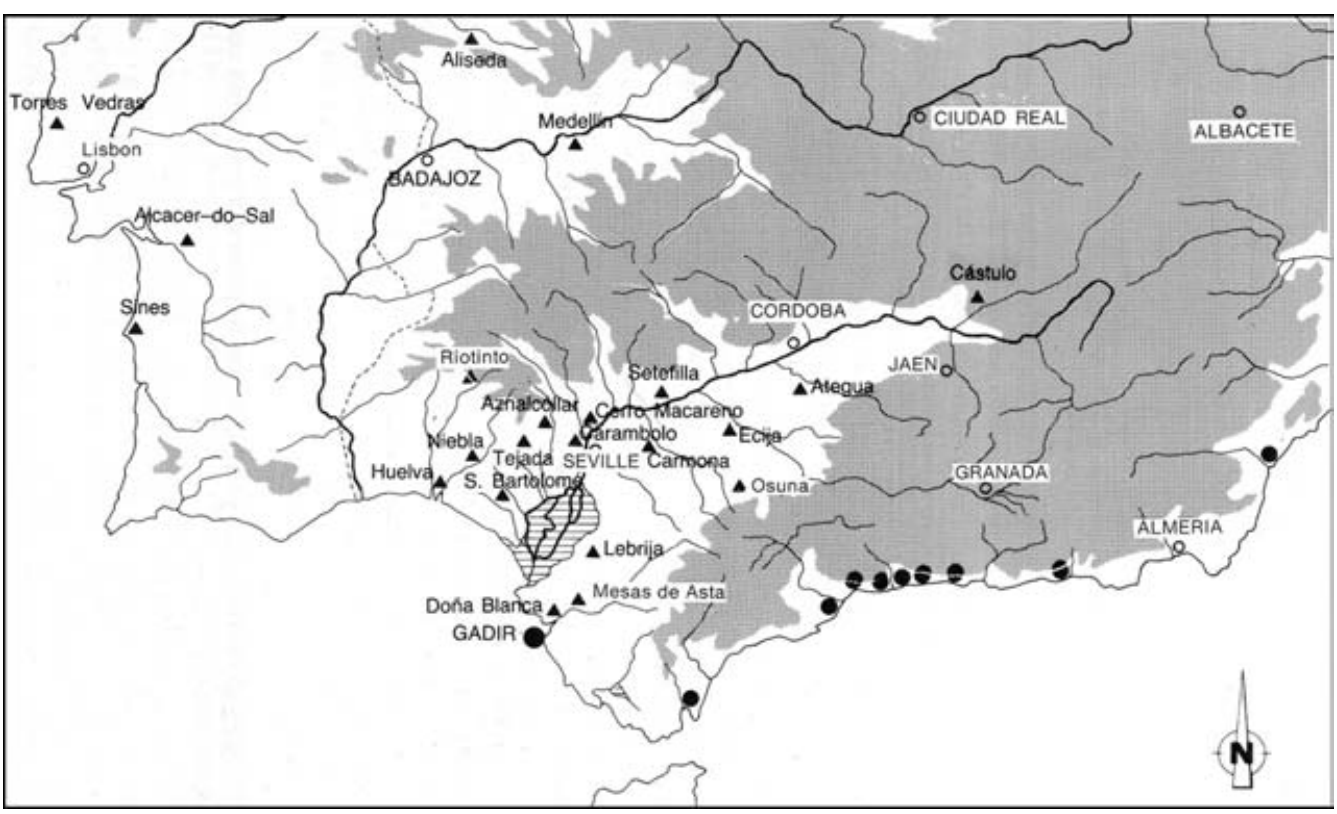

Figure 1. Map of the south of the Iberian Peninsula showing the area of Tartessos. Triangles indicate Tartessian settlements, circles indicate Phoenician colonies. From Aubet 1993: 219.

\& Keel 1998; Arav \& Freund 1998; Ornan 2001) (cf. Figure 6). The purpose of this paper is to review the images, symbols and artefacts that belong, as we shall see, to both cultural spheres, and to study the cultural dialogue that they imply.

\section{The slabs and stelae of Tartessos}

The Tartessic stelae originated in the Tagus valley in the Late Bronze period and reached their maximum geographic expansion and complexity at the beginning of the orientalising period (Barceló 1989; Galán 1993; Celestino 2001a). There are two main classes of monument: the so-called slabs (or basic stelae) and the stelae proper. The slabs are characterised by the invariable presence of a shield, a spear and a sword, and always present the same arrangement with the shield at the centre of the composition and the spear and the sword lying horizontally above and below the shield, respectively (Figure 2). The slabs reserve a blank space with no decoration on the upper and lower parts, and are usually $1.70 \mathrm{~m}$ long, which has prompted the hypothesis that they would be used to cover inhumation cists. The distribution of the slabs is limited to the Tagus valley, but over time they apparently spread slowly towards the Guadiana valley. New objects of prestige and weapons of Atlantic origin were then added to the graphic repertoire, such as carp's tongue swords or conical helmets (cf. Figure 3). As the slabs started appearing also in the south, they incorporated new elements of clear Mediterranean origin, such as the first chariots, mirrors, ivory combs and pins, or fibulae, but they maintained the same form of monument and the basic arrangement of the images engraved on it. This development probably belonged to the stage previous to the Phoenician colonisation. During this stage, loosely called 'pre-colonisation', there were more or less regular contacts with the Levantine peoples, but the social system of 


\section{S. Celestino Pérez \& C. López-Ruiz}

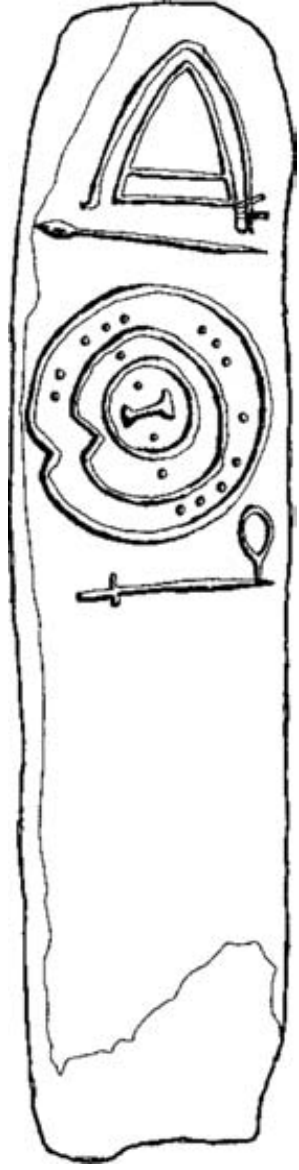

Figure 2. Basic stela from Santa Ana de Trujillo (Cáceres), Spain, $44 \mathrm{~cm}$ wide by $185 \mathrm{~cm}$ high. the indigenous groups was not essentially altered (AlmagroGorbea 1998; Celestino 1998, 2001a; Moreno 1999).

We can start talking about 'stelae proper' in examples where the lower end of the stone is left undecorated and narrowed in order to be fixed in the floor. These stelae are found in the Guadiana and Guadalquivir valleys (that is, more to the south-west). This new form coincides, very significantly, with the introduction of the anthropomorphic element in the composition, while the shield, spear, sword and other Mediterranean prestige and luxury goods that accompany the deceased are relegated to a secondary place. Some of these are two-wheeled chariots, musical instruments such as lyres or crotaloi, a special type of fibula called 'elbow-type' because of its marked angular shape and, very important for our argument, helmets with horns. These helmets definitively replace the older conic helmets of Atlantic type (see Figures 4 and 5 for two stelae with horned helmets, and Figure 3 for the evolution of the helmets).

It is generally believed that this substantial change not only in the shape of the stelae but also in the rich decoration that they by now incorporated, clearly associated with social prestige, was simultaneous with the introduction of cremation burials. This funerary ritual, already extensive in the Mediterranean basin, appeared only at this time in the Iberian Peninsula. It was probably first applied to the most prestigious burials and must have coexisted with the inhumation system for some generations. Furthermore, the fact that all the warrior stelae present a fairly homogeneous iconography leads us to think that they had reached some degree of systematisation as to their symbolic meaning, perhaps indicating that the represented men were deified or at least given the status of heroes.

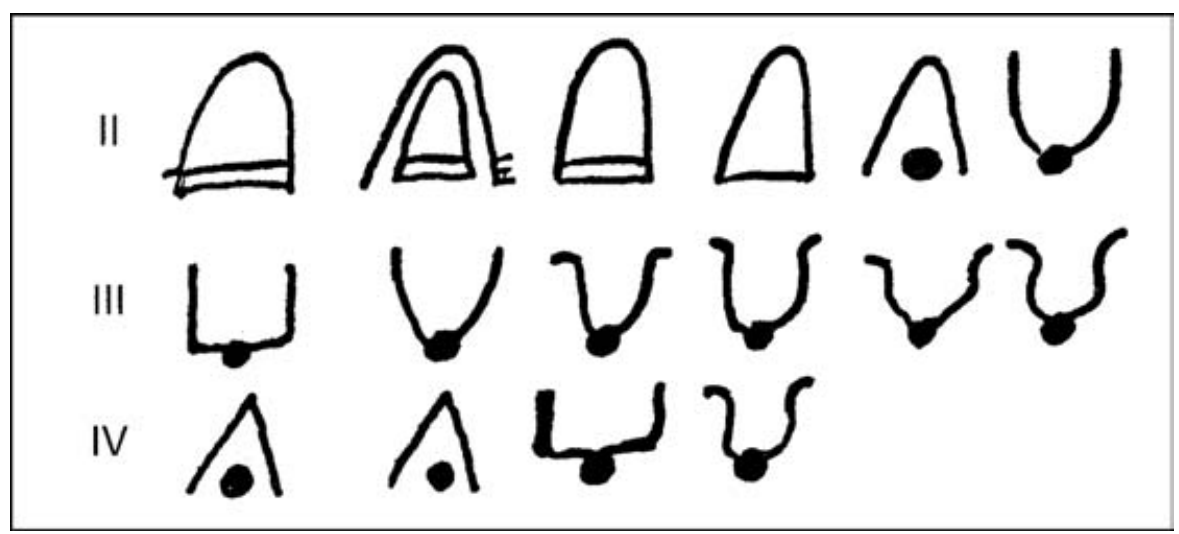

Figure 3. Iconographic evolution of the helmets. 
Taking into account the area in which the latest warrior stelae appear, along the lower Guadalquivir valley, and also the elements represented in them, they can be dated without much difficulty to the ninth and eighth centuries BC, coinciding with the settlement of Phoenician colonists in this area of the Iberian Peninsula. These warriors were not only the first elite members to receive exotic products and adopt new technologies from the Levant, but they would also have assimilated and spread out the new funerary ritual, which still coexisted with older traditions (Torres 1999).

\section{Beth-Saida and other parallels: iconography and interpretation}

At the other end of the Mediterranean basin, the stela found at Beth-Saida (Figure 6) has become the first monument of its kind to be found in a reliable archaeological context. This factor allowed its discoverers to date it with some certainty to the second half of the eighth century BC. The broken stela was found near the foot of a 'high place' (cultic spot) beside one of the monumental gates of Beth-Saida. Carved on local basalt stone, the Beth-Saida stela bears a very schematic anthropomorphic relief with a bull's head. Its horns, with conspicuous ears at their base, make an almost complete circle, while two symmetrical arches represent the arms and legs, and the body takes the form of a straight pillar. A sword crosses the pole diagonally from right to left. It has a wide blade and a seemingly solid curved handle. Finally, a rosette composed of four small spheres was added between the left arm and the sword blade. In the same context, according to the discoverers, other cultic objects were found, such as incense burners, a basin used for libations and three other non-iconic stelae (Barnett \& Keel 1998).

Only three stelae similar to the one at Beth-Saida were previously known. The first is in the Turkish Museum of

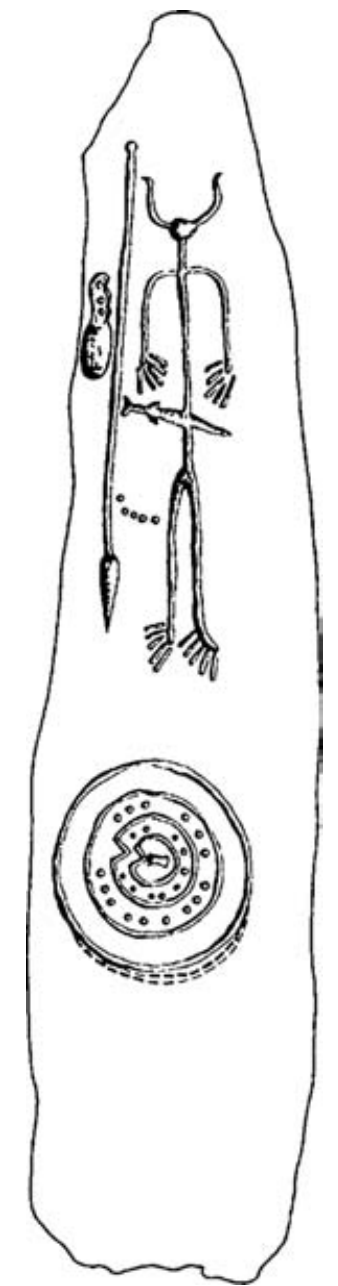

Figure 4. Stela from Magacela (Badajoz), Spain, $55 \mathrm{~cm} \times 145 \mathrm{~cm}$ Gaziantepe, close to the Syrian border, in the region of Harran, north of Aleppo (see map in Figure 7 and stela in Figure 8). Its archaeological context and exact provenance, however, are unknown (Krebernik \& Seidl 1997: 106). Despite the absence of a sword, the representation is almost identical to that of Beth-Saida, especially the bull's head topped by the massive horns of circular shape and the rosette under the left arm of the figure. The other two stelae are also very similar and practically identical to one another (Figure 9). They were found in the south of Syria, in the region of the Hauran, east of the Sea of Galilee. The first stela was reused as part of a Roman funerary structure of the second century AD, while the second one appeared during modern construction works (Krebenik \& Seidl 1997: 107, 108). 


\section{S. Celestino Pérez \& C. López-Ruiz}

All four stelae share a common iconography, namely, an anthropomorphic pillar, long circular horns with conspicuous ears, a sword at the waist (in three of them) and a four-

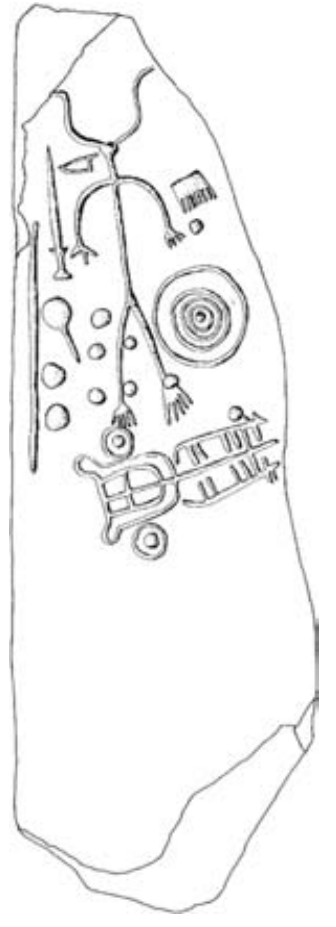

Figure 5. Stela from Fuente de Cantos (Badajoz), Spain, $79 \mathrm{~cm} \times 231 \mathrm{~cm}$.

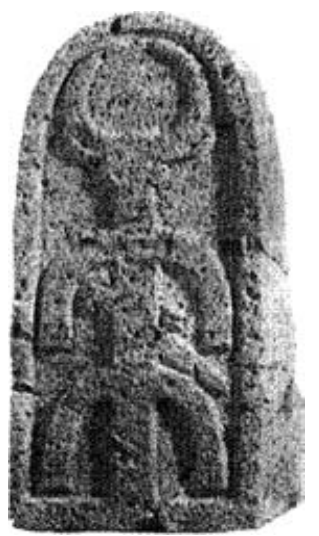

Figure 6. Stela from BethSaida, Israel. Israel Museum. petalled rosette under the left arm. Besides this, the two Damascus Museum stelae present an additional rosette of eight petals in the circular space produced by the horns. The three previously known stelae were dated to the eighth to seventh centuries BC, based on iconographic criteria and comparison with similar motifs in other monuments, mainly with the Assyrian stela of Adad-Nirari III which came from the heart of Assyria and dated between $810 \mathrm{BC}$ and 783 BC (Tadmor 1973; Krebernik \& Seidl 1997: 109). These motifs (the pole topped with a bull's head, the rosette, etc.) also appear on some bronze objects of unknown provenance in the Museum of Damascus (Seyrig 1959: 43-8, pl. VIII-X; Krebernik \& Seidl 1997: 106-7) (Figure 10) and on a stamp seal of unknown provenance dated to the eighth to seventh centuries BC now in the Israel Museum (Figure 11). The recent appearance of the stela from Beth-Saida now provides us with a more solid point of reference for the dating of these three other Syro-Palestinian stelae (Ornan 2001; Barnett \& Keel 1998).

The interpretation of the origin and meaning of these symbols (the pole with a bull's head or with a crescent symbol, the rosette), which seem to emerge at some point in the Fertile Crescent, is certainly complicated. The lunar god of fertility, Sin, appears to be connected to the figure of the bull (in turn a symbol of fertility) from the third millennium BC in Mesopotamia (Ornan 2001: 2-3). On the other hand, the bull as a representative of the storm god Baal/Haddad is especially characteristic of the SyroPalestinian region, at least since the second millennium BC. In fact, the association of the two divinities might have worked in both directions (Ornan 2001: 20). In any event, given the broad geographic context of the stelae in Syria-Palestine and the WestSemitic character of the bull as a storm god, it seems reasonable to interpret these figures as representations of the storm god with additional lunar attributes, associated with the horns in crescent shape. The rosettes, in turn, belong to a feminine realm associated with the fertility goddess Ashtarte, whose relationship with the West-Semitic storm god is often represented in objects around the eighth century BC and coming from Syro-Palestinian contexts (cf. Figures 10 and 11).

However this symbolism might have worked, we are confronted with the representation of a creature or a divinity with bull head and warrior attributes, carved on stelae of very similar types and distributed through the realm of the Aramaic kingdoms with a predominantly West-Semitic population. In the case of Beth-Saida, we can add with some degree of certainty that the stela was 


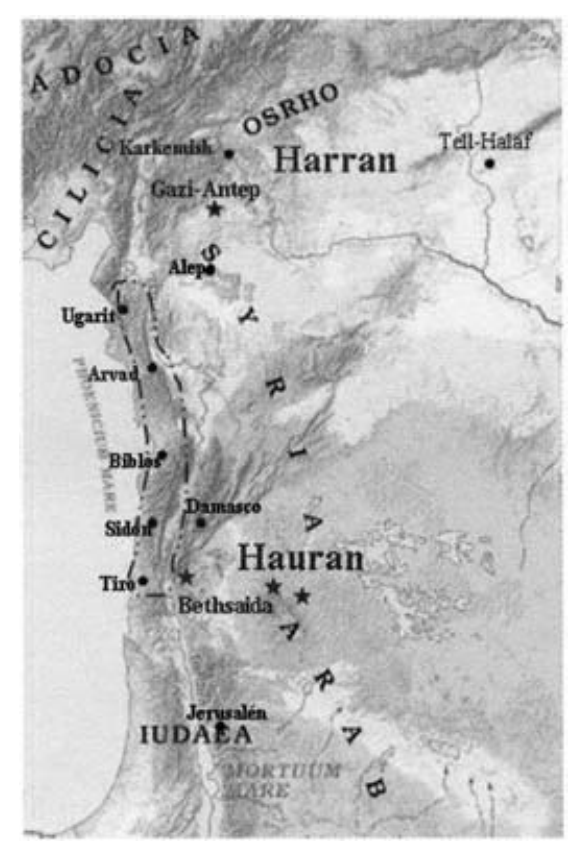

Figure 7. Map of the Levant showing the location of the warrior-bull stelae.

associated with religious activities. Finally, we should recall that the practice of setting up stelae and their association with the primordial deities is deeply rooted among the north-west Semitic peoples, from the Canaanites of Ugarit to the Hebrews and the Phoenicians in the Iron Age and later. The most conspicuous examples are the well-attested mazzebot or standing stones in Israel, which are betyls or cultic stones related to fertility and ancestry (Avner 2001: 39-41). The extended use of stelae in the Phoenician tophet or children's graveyards dedicated to the goddess Tanit also belongs to this tradition (Moscati 1989: 91-2).

\section{Discussion}

It is precisely this trend of Phoenician tradition which interests us, for the so-called Phoenicians, understood as comprising various peoples from the Syro-Palestinian region (Lebanon, Syria, Cilicia), extended their commercial routes throughout the Mediterranean at least from the end of the ninth century BC (Baurin \& Bonnet 1992; Aubet 1993; Bartoloni 1990; Niemeyer 1995), transmitting their culture and new technologies and provoking deep transformations in the societies they came into contact with. The Iberian Peninsula was one of these areas, previously relatively isolated from the Levantine world until it became part of the route of the first explorers and colonists. The warrior stelae from the area of Tartessos in south-west Spain have long been considered unique witnesses of these relationships. It is particularly interesting in this context that they show certain analogies with the Levantine stelae recently brought to the attention of the scholarly community.

If we focus on the chronologically latest stelae found around the Guadiana and Guadalquivir valleys, we see that these monuments underwent a transformation, which drew them closer to the Near Eastern stelae presented here, not only in terms of iconography but also of chronological range. Furthermore, there is an association of both groups of stelae with sacred and, perhaps, funerary realms. While two of the Syro-Palestinian stelae lack archaeological context, the one at Beth-Saida was unearthed in what seemed to be a sacred precinct, and the one from Hauran was reused in a Roman funerary monument, which might indicate a certain continuity in the meaning and use of this type of stela in later periods. Many of the Tartessic stelae also appear reused, some of them in Roman times, with inscriptions often added to them in order to signal the grave. This is the case of the stelae of Ibahernando (Celestino 2001a: 342) or Chillón (Fernández Ochoa \& Zarzalejos 1994). In turn, the connection of the Tartessic stelae with the funerary world seems to be quite evident, without denying other possible interpretations of their function (Ruíz-Galvez \& Galán 1991; Galán 1993). New findings such as the stela from Setefilla (Aubet 1997) and recent studies of the 


\section{S. Celestino Pérez \& C. López-Ruiz}

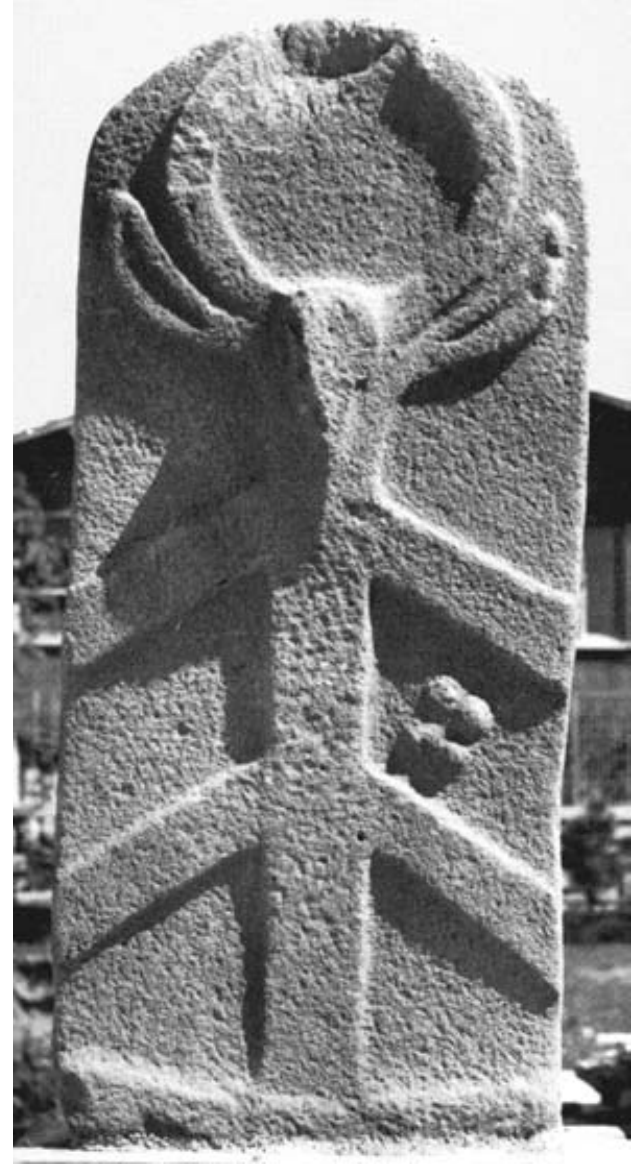

Figure 8. Stela from Harran, Museum of Gaziantepe. Ph. P. Calmeyer (in Krebernik \& Seidl 1997: plate 3). forms, iconography and dispersion of the documented cases support this interpretation (Celestino 2001a).

In this sense, the finding of other stones shaped like stelae but lacking decoration near the famous stela from Beth-Saida is significant, since this pattern is also noted in the Tartessic stelae. The latter are often grouped in reduced spaces, as is the case in sites such as Cabeza del Buey, Zarza Capilla, Écija, El Viso or Torrejón el Rubio. In some of these sites undecorated stones with the same shape as the stelae have been found, in areas where this type of stone cannot be obtained locally (e.g. Cabeza del Buey and El Viso). This suggests that the stelae worked as a highly valued method of signalling tombs or places of some funerary significance (e.g. as cenotaphs). It is the case also in Near Eastern and Mediterranean archaeology in general that particular stelae with special symbolism appear surrounded by other simple stelae, which either mark less important burials or are used to enclose the sacred precinct. The stelae found in the Negev desert (Israel), for instance, dated to the end of the Neolithic period, are grouped following different patterns and have both funerary and ancestors' cult function (Avner 2001).

More importantly, we have to consider the iconographic transformation that the stelae underwent during the orientalising period. It is then that they incorporated Mediterranean elements of the warrior's panoply, and the represented scenes show a clear assimilation to the funerary rituals that characterised other areas of the Mediterranean world. We can see this in the stela from Ategua (Bendala 1977: 191) (Figure 12) and Zarza Capilla III (Celestino 2001a: 383).

The assimilation of a Mediterranean religious iconography, always adapted to the preexisting indigenous beliefs, can also be traced at different levels in the archaeological record. Perhaps the most obvious evidence of this has survived in jewellery, where we have representations of trees of life, lotus flowers, crescent moons, rosettes, etc., which sometimes also appear as decorative motifs in the local pottery (Belén \& Escacena 1998). The stelae themselves, therefore, provide us with important clues to understanding this change, no doubt only a hint of the deeper ideological and religious transformations that must have taken place in the period of Phoenician colonisation. 


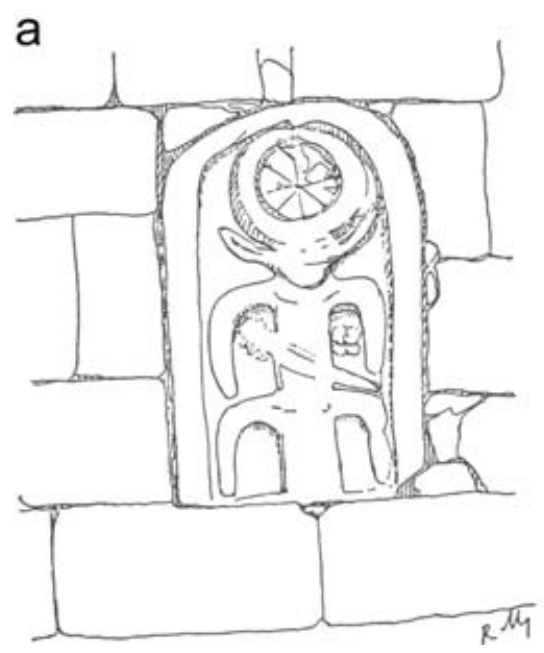

b

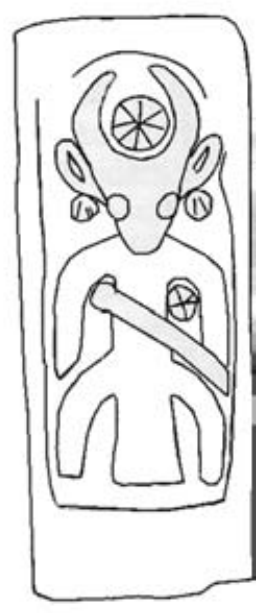

Figure 9. Stelae from Hauran region, Museum of Damascus. After Krebernik \& Seidl 1997 (illustrations 4 and 5).

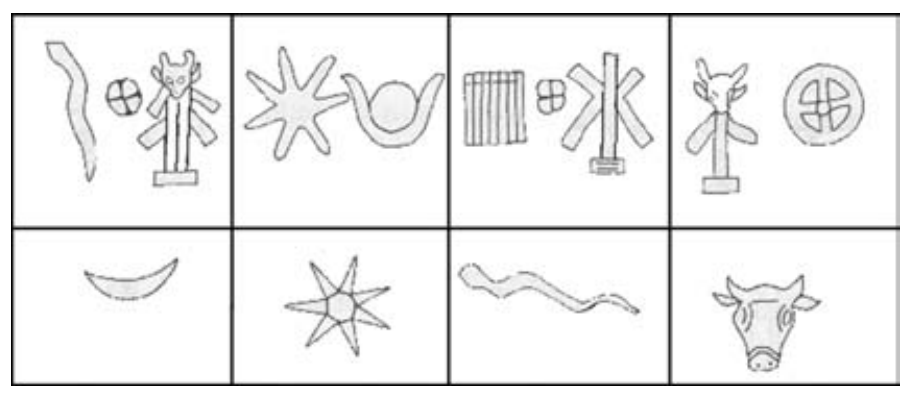

Figure 10. Icons represented in the bronze objects today in the Museum of Damascus. After Krebernik \& Seidl 1997 (illustration 3, p. 107).

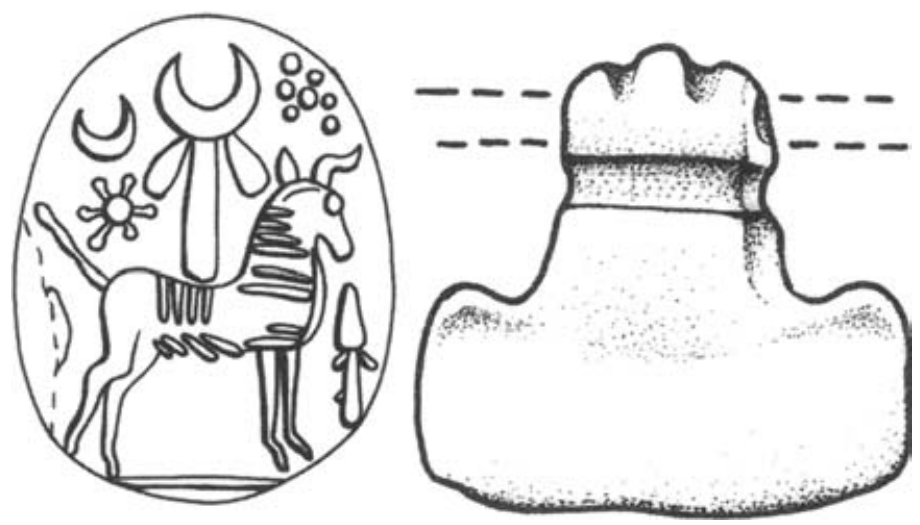

Figure 11. Stamp seal of unknown provenance, Israel Museum. After Ornan 2001 (Figure 15, p. 20). 


\section{S. Celestino Pérez \& C. López-Ruiz}

Last but not least, the war-like aspect of these stelae is constant from the beginning to the end of their development. However, as we have pointed out, the weapons and plainly

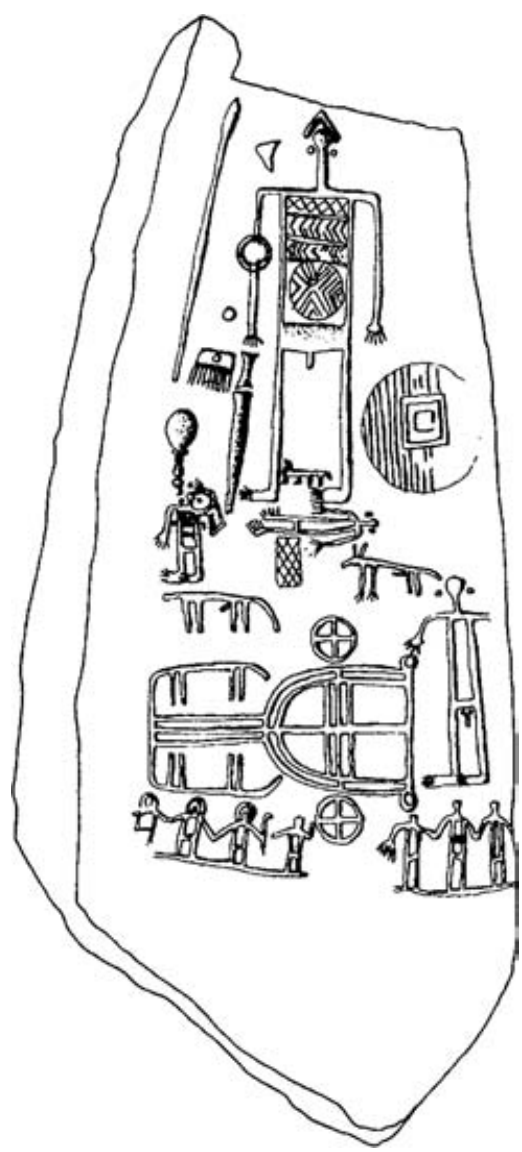

Figure 12. Stela from Ategua (Córdoba), Spain, $50 \mathrm{~cm} \times 92 \mathrm{~cm}$. war-like aspect of the stelae give way to a progressively greater importance of the prestige objects and funerary scenes. The horned helmet appears in the Tartessic stelae at this last stage, precisely at the same time that the warrior-bull of the SyroPalestinian stelae is portrayed at the other end of the Mediterranean basin.

The assimilation of the symbol of the warrior attired as a bull in the Tartessic stelae can be associated with the broad presence of the bull image in Mediterranean cultures of the time. A very important example is that of the so-called Cypriot ingots, also known as 'ox-hide ingots', due to their shape imitating an extended bull skin. These pieces have been widely found in the Iberian Peninsula, invariably associated with cultic spaces, either funerary or ritual (Celestino 1994; Maier 2003). Numerous such copper ingots are well known from the fifteenth century BC in the Central and Eastern Mediterranean, especially in Sardinia, Sicily and Cyprus, as well as in the Egyptian and Syro-Palestinian cultures (Lagarce \& Lagarce 1997). Their shape is usually explained as a consequence of the use of the bull or ox skin as exchange currency in the Late Bronze Age, which prompted their association with human and divine power. Their symbolic importance then spread throughout the Mediterranean basin. It is worth mentioning here a statue known as the 'god of the ingot', found at the sanctuary of Enkomi (Cyprus) and dated to the twelfth century BC (Schaeffer 1965). The statue, only $35 \mathrm{~cm}$ high, undoubtedly represents the Smiting God, the weather god of the north-west Semites, represented as a warrior wearing a short skirt (in an Egyptian style) carrying a spear, a shield and a horned helmet, and standing on an ox hide. It is not by chance that in the same building a number of bull skulls with their horns were found (Courtois 1971).

The sacred importance of the bull can be noted in many other manifestations. For instance, the main animal sacrificed to the north-west Semitic weather god Baal Haddad was the bull. In the same way, bulls were also the highest items of sacrifice for the Israelite god Yahweh (cf. Bible, 1 Kings 18: 2-35; Maier 2003: 97). These associations of the bull and the storm god reached the main pantheons of the Mediterranean; in the Graeco-Roman world the figure of Zeus-Jupiter adopted the same storm attributes as Baal, and myth represents Zeus taking the shape of a bull in order to kidnap the Phoenician princess Europa and carry her away to Crete. 


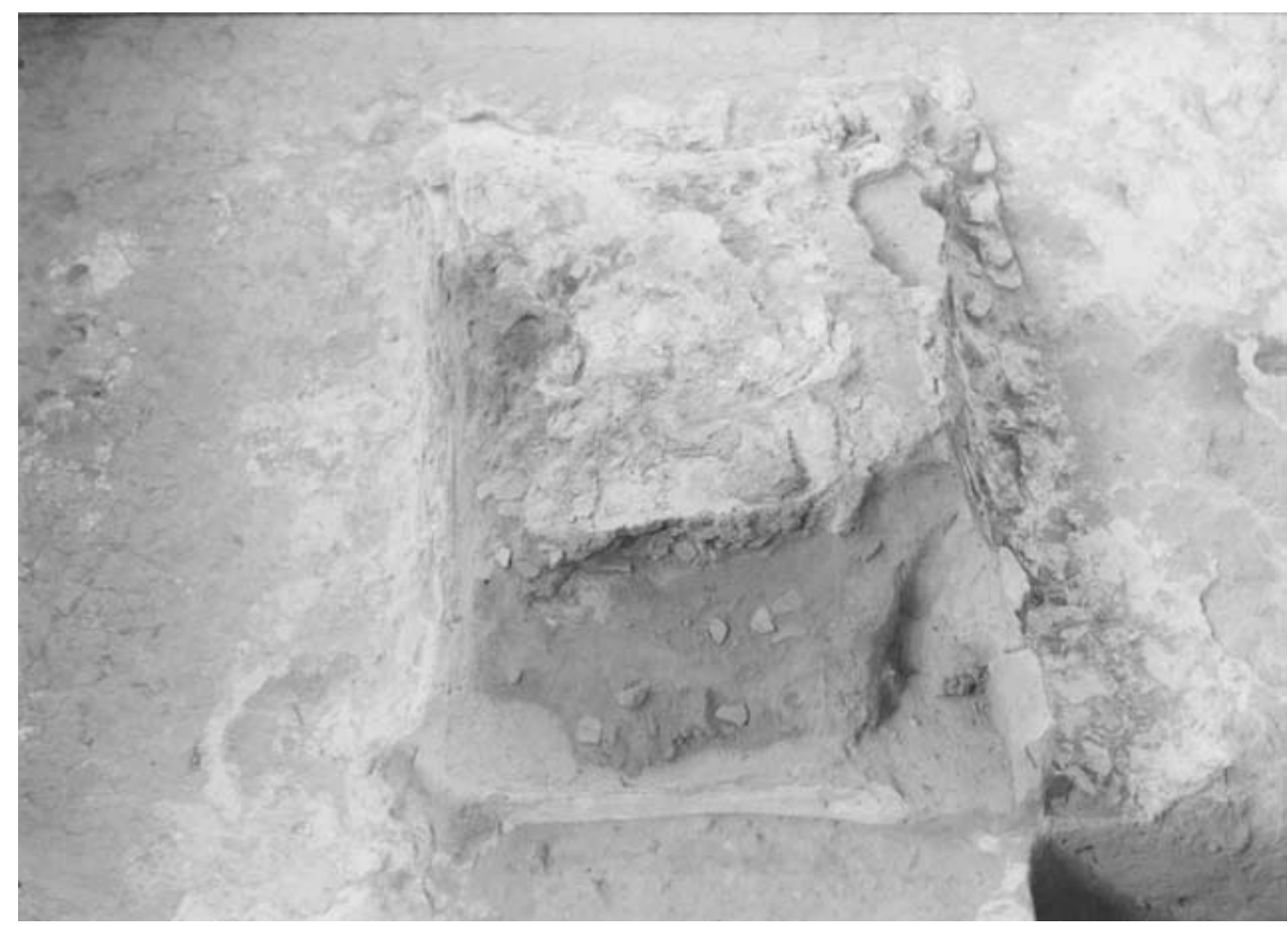

Figure 13. Bull-skin-shaped altar from Cancho Roano B (Badajoz), Spain, $45 \mathrm{~cm} \times 98 \mathrm{~cm}$.

Returning to ancient Iberia, and despite the generalised gap in the record of the ox-hide ingots or their representations between the twelfth and the seventh centuries $\mathrm{BC}$, this type of oriental Mediterranean motif seems to have had a clear impact on the iconography that appears in the Iberian Peninsula precisely during the orientalising period. It is precisely then that the horned-warrior stelae start appearing, and the symbols associated with the bull spread widely throughout the Tartessic world. Some examples are the gold pectorals from El Carambolo, the treasure of Ebora or the ivory box of La Joya (Celestino 1994). Most significant in this sense is a specific type of altar with the shape of a bull skin that appears also in the Tartessic area, such as the seventh century BC altar at Caura's sanctuary III (Coria del Rio, Seville) dedicated to Baal Saphon (Escacena \& Izquierdo 2001: 13), or the one unearthed in the sanctuary of Cancho Roano B, dated to the end of the sixth century BC (Celestino 2001b: 30) (see Figure 13). The continuity of these altars of extended bull-hide shape is well represented in the later Iberian culture, where they are identifiable in royal tombs, such as Pozo Moro (Almagro-Gorbea 1983: 185) and in necropolises such as Los Villares (Albacete) (Blánquez Pérez 1992: 255) or Castillejos de Baños (Murcia) (García Cano 1992: 321). Altars of this type have appeared in other areas of the Iberian Peninsula in similar contexts as the Tartessic ones (Abad \& Sala 1997: 95; G.I.P. 2005; Ortega Blanco \& del Valle Gutierrez 2004).

Moreover, what might have been the model for this kind of altar in the Iberian Peninsula has been recently unearthed in the central space of the El Carambolo sanctuary in Seville. 


\section{S. Celestino Pérez \& C. López-Ruiz}

This was the first centre where permanent oriental presence can be detected at the core of Tartessic civilisation. The discovery of a large 'ox-hide altar' in one of the chapels of the sanctuary seems to be the key to understanding the diffusion of this religious symbol during the orientalising period and its persistence in Iberian society until at least the fifth century BC (Fernández Flores \& Rodríguez Azogue 2005).

\section{Conclusion}

The importance of the bull in Tartessic and Iberian religion is unquestionable (Delgado 1996), and must have been a critical factor in the adaptation of representations of Baal (and of his consort Ashtarte, goddess of fertility, also well represented in the Tartessic realm) by the indigenous groups. Also very important in relation to the stelae is the warrior character of Baal and the assimilation of those features in the central and western Mediterranean, as is well represented by the Cypriot god and the Sardinian warriors wearing horned helmets, and carrying shields and spears in a very similar fashion to the warriors of the Tartessic stelae.

The successful introduction of a god such as Baal into these regions was no doubt instigated by the first Levantine merchants launching commercial activity in these areas and slowly settling down in them as Phoenician colonisation advanced and fostered indigenousoriental interaction. Whether the bull-warrior of the Tartessic stelae represents a god (Baal or a similar indigenous god) or a Tartessic hero or chief in the mode of the first Greek Geometric funerary representations (cf. especially Ategua stela and Dipylon vases) is difficult to say. The precise function and meaning of both groups of stelae, the Syro-Palestinian and the Tartessic, are still not totally certain. But it is clear that the first warrior stelae present only the weapons and conical helmets. It is only as the first colonial encounters with the Phoenicians took place, that the anthropomorphic figures start to appear, surrounded by his weapons and attired with horned helmets (or bull heads?). The assimilation of the warrior-bull motif must have been adapted to the pre-existing use and meaning of the same objects and their decoration in the indigenous culture. These traditions were enriched and only partially transformed by the vibrant relationships with the oriental peoples at a particular time period. At the same time, this assimilation was made easier by a certain degree of shared cultural features and perhaps beliefs throughout the Mediterranean basin, such as the importance of the bull in relation to aspects of human, natural and divine power.

A case such as this, where imposition or borrowing does not seem to account for the evidence, suggests that the transformation of the iconography in the Tartessic stelae might have been the product of a longer and more balanced exchange. In this model, the necessary degree of integration had already taken place between permanent settlers of Levantine background (e.g. those familiar with the bull-warrior god represented in the Syro-Palestinian stelae) and local populations (e.g. those familiar with the long indigenous tradition of setting up stelae and decorating them with warrior-like motifs). The active participation of both communities is, in our view, the key to understanding the monuments and the process of cultural change in this region. This implies a very different picture from the generally passive and receptive role often ascribed to the native and more primitive populations in colonial studies. 


\section{Warrior stelae from Tartessos}

\section{Acknowledgements}

Preliminary versions of this work were presented at the 'VII Congreso Internacional de Estelas Funerarias', sponsored by the Fundación Marcelino Botín, in Santander (Spain), October 2002 (published in Celestino \& López-Ruiz 2004), and at the 'Ancient Societies Workshop' of the University of Chicago in November 2003. We would like to thank the audience in both meetings for their enthusiasm and useful feedback. Special thanks go to Leslie Warden for her help with the English version and to Christopher Faraone, Margarita Díaz-Andreu and Fernando Lozano for their important suggestions on this work. All mistakes and flaws are of course only ours.

\section{References}

Abad, L. \& F. Sala. 1997. Sobre el posible uso cúltico de algunos edificios de la Contestania ibérica. Espacios y lugares cultuales en el mundo ibérico. Quaderns de Prehistoria y Arqueologia de Castelló 18: 91-102.

Almagro-Gorbea, M. 1983. Pozo Moro: el monumento orientalizante, su contexto sociocultural y sus paralelos en la arquitectura funeraria ibérica. Madrider Mitteilungen 24: 177-392.

-1998. Precolonización y cambio sociocultural en el Bronce Atlántico, in Intercâmbio e comércio: as "economias" da Idade do Bronce: 81-100. Lisboa: Universidade de Lisboa.

Arav, R. \& R. Freund. 1998. The bull from the sea: Geshur's chief deity? Biblical Archaeology Review January/February: 42.

Aubet, M.E. 1993. The Phoenicians and the West. Cambridge: Cambridge University Press (original title Tiro y las colonias fenicias de Occidente. Barcelona: Crítica, 1987).

-1997. A propósito de una vieja estela. Saguntum 30 (Festschrift M. Gil-Mascarell) II: 163-72.

Avner, U. 2001. Sacred stones in the desert. Biblical Archaeology Review May/June: 31-41.

Barceló, J.A. 1989. Las estelas decoradas del Suroeste de la Península Ibérica, in M.E. Aubet (ed.) Tartessos. Arqueología protohistórica del Bajo Guadalquivir: 189-208. Sabadell: Ausa.

Barnett, M \& O. Keel. 1998. Mond, Stier und Kult am Stadttor, die Stela von Beth-Saida (et-tell) (Orbis Biblicus et Orientalis 161). Fribourg (Switzerland)/Universitätsverlag-Göttingen: Vandenhoeck \& Ruprecht.

Bartoloni, P. 1990. Aspetti precoloniali della colonizzazione fenicia in Occidente. Rivista di Studi Fenici 18 (2): 195-213.

Baurin, C \& E.C. Bonnet. 1992. Les phéniciens. Marins des trois continents. Paris: Armand Colin.

Belén, M. \& J.L. Escacena. 1998. Testimonios religiosos de la presencia fenicia, in J.M. Galán, J.-L. Cunchillos \& J.A. Zamora (ed.) Actas del Congreso El Mediterráneo en la Antigüedad: Oriente y Occidente. Sapanu, publicaciones en Internet II (http://www.labherm.filol.csic.es).
Bendala, M. 1977. Notas sobre las estelas decoradas del Suroeste y los orígenes de Tartessos. Habis 8: 117-205.

BlÁNQuez Pérez, J.U. 1992. Las necrópolis ibéricas del sureste de la Meseta, in J.U. Blánquez \& V. Antona (ed.) Congreso de Arqueología Ibérica: Las Necrópolis. Serie Varia 2: 235-78. Madrid: Universidad Autónoma de Madrid.

Celestino, S. 1994. Los altares en forma de lingote chipriota de los santuarios de Cancho Roano. Revista de Estudios Ibéricos 1: 291-304.

-1998. La Precolonización a través de la periferia tartésica, in J.M. Galán, J.-L. Cunchillos \& J.A. Zamora (ed.) Actas del Congreso El Mediterráneo en la Antigüedad: Oriente y Occidente. Sapanu: publicaciones en Internet II (http://www.labherm.filol.csic.es).

-2001a. Estelas de guerrero y estelas diademadas. La Precolonización y formación del mundo tartésico. Barcelona: Bellaterra.

-2001b. Los santuarios de Cancho Roano. Del indigenismo al orientalismo arquitectónico, in D. Ruiz Mata \& S. Celestino (ed.) Arquitectura Oriental y Orientalizante e la Península Ibérica: 17-56. Madrid: CEPO-CSIC.

Celestino, S. \& C. López-Ruiz. 2004. El motivo del toro guerrero en las estelas sirio-palestinas y sus analogías con las estelas tartésicas. Actas del VII Congreso Internacional de Estelas Funerarias (2 vols), vol I: 95-108. Santander: Fundación Marcelino Botín.

Courtois, J.C. 1971. Le sanctuaire du dieu au lingot d'Enkomi-Alasia, in C.F.-A. Schaeffer (ed.) Alasia I: 151-362. Paris: Lib. Klincksiek.

Delgado, C. 1996. El toro en el Mediterráneo. Análisis de su presencia y significado en las grandes culturas del mundo antiguo. Madrid: Universidad Autónoma de Madrid.

Escacena, J.L. \& R. IzQuierdo. 2001. Oriente en Occidente: arquitectura civil y religiosa en el barrio fenicio de la Caura tartésica, in D. Ruiz Mata \& S. Celestino (ed.) Arquitectura Orientaly Orientalizante e la Península Ibérica: 123-57. Madrid: CEPO-CSIC. 


\section{S. Celestino Pérez \& C. López-Ruiz}

Fernández Flores, A. \& A. Rodríguez Azogue. 2005. Nuevas Excavaciones en el Carambolo Alto, Camas (Sevilla). Resultados Preliminares, in S. Celestino \& J. Jiménez (ed.) El Periodo Orientalizante. Actas del III Simposio Internacional de Arqueología de Mérida. Anejos del Archivo Español de Arqueología xxxv: 843-72. Madrid: CSIC.

Fernández Ochoa, C. \& M. ZarZalejos. 1994 La estela de Chillón (Ciudad Real). Algunas consideraciones acerca de la funcionalidad de las estelas de guerrero del Bronce Final y su reutilización en época romana, in C. de la Casa (ed.) V Congreso Internacional de Estelas Funerarias. Soria: Diputación Provincial de Soria.

GALÁn, E. 1993. Estelas, paisaje y territorio en el Bronce Final del Suroeste de la peninsula ibérica. Complutum Extra 3. Madrid: Universidad Complutense de Madrid.

García CANO, J.M. 1992. Las necrópolis ibéricas en Murcia, in J.U. Blánquez \& V. Antona (ed.) Congreso de Arqueología Ibérica: Las Necrópolis. Serie Varia 2: 313-47. Madrid: Universidad Autónoma de Madrid.

G.I.P. (Grupo de Investigación de Prehistoria, Universidad de Lleida) 2005. Dos hogares orientalizantes de la fortaleza de Els Vilars (Arbeca, Lérida), in S. Celestino \& J. Jiménez (ed.) El Periodo Orientalizante. Actas del III Simposio Internacional de Arqueología de Mérida. Anejos del Archivo Español de Arqueología xxxv: 651-67. Madrid: CSIC.

Krebernik, M. \& U. Seidl. 1997. Ein Sschildbeschlag mit Bukranion und alphabetischer Inschrift. Zeitschrift für Assyrologie 87: 101-11.
Lagarce, E. \& J. Lagarce. 1997. Les lingots "en peau de boeuf," objets de comerce et symboles idéologiques dans le monde Mediterranée. Revue des études phéniciennes-puniques et des antiquités libyennes 10: 73-97.

Maier, J. 2003. El lingote en rama chipriota o piel de toro: símbolo divino de la antigua Iberia. Fiestas de toros y Sociedad. Colección Tauromaquias 5: 85-106.

Moreno, F. 1999. Conflictos y perspectivas del período precolonial tartésico. Gerión. 17: 149-78.

Moscati, S. 1989. Tra Tiro e Cadice: Temi e problemi degli suti fenici. Studia Punica 5. Roma.

Niemeyer, H.G. 1995. Expansion et colonisation, in V. Krings (ed.) La civilisation phénicienne et punique: 247-67. Leiden: Brill.

Ornan, T. 2001. The bull and its two masters: moon and storm deities in relation to the bull in Ancient Near Eastern art. Israel Exploration Journal 51: 1-26.

Ortega Blanco, J. \& M. del Valle Gutierrez. 2004. El poblado de la Edad del Hierro del Cerro de la Mesa (Alcolea del Tajo, Toledo). Primeros resultados. Trabajos de Prehistoria 61 (1): 175-85.

Ruíz-Gálvez, M.L. \& E. Galán. 1991. Las estelas del suroeste como hitos de vías ganaderas y rutas comerciales. Trabajos de Prehistoria 48: 257-73.

Schaeffer, C.F.A. 1965. An ingot god from Cyprus. Antiquity 39: 56-7.

SeYrig, H. 1959. Antiquités syriennes. Syria 36: 38-89.

TADMOR, H. 1973. The historical inscriptions of Adad-Nirari III. Iraq 35: 141-50.

Torres, M. 1999. Sociedad y mundo funerario en Tartessos. Bibliotheca Archaeologica Hispana 3. Madrid: Real Academia de la Historia. 